BIOFARM

Jurnal Ilmiah Pertanian

ISSN Print: 0216-5430; ISSN Online: 2301-6442

Vol. 16, No. 2, Oktober 2020

\title{
Pengaruh Pemberian Variasi Kensentrasi GA3 pada Pertumbuhan Beberapa Macam Klon Kakao (Theobroma cacao L.)
}

\author{
The Effect Of Variations In The Concentration Of $\mathrm{GA}_{3}$ On The Growth Of \\ Several Types Of Cocoa Clones (Theobroma cacao L.)
}

\author{
Karina Widiawati ${ }^{1 *}$ Eka Adi Supriyanto $^{1}$ \\ ${ }^{1}$ Program Studi Agroteknologi, Fakultas Pertanian, Universitas Pekalongan \\ *Korespondensi Penulis: karinawidiawati410@gmail.com
}

\begin{abstract}
ABSTRAK
Kakao merupakan salah satu komoditas perkebunan, berperan penting dalam meningkatkan devisa negara. Penyediaan bibit kakao masih belum mencukupi dan kualitas benih yang dihasilkan masih rendah. Penelitian bertujuan untuk mengetahui pengaruh pemberian konsentrasi giberelin (GA3) dan macam klon terhadap pertumbuhan bibit kakao dan interaksinya. Penelitian dilakukan di Desa Kenconorejo, Kec. Tulis, Kab. Batang. Rancangan percobaan yang digunakan Rancangan Acak Kelompok Lengkap (RAKL) dengan perlakuan konsentrasi GA3 (kontrol, 100, 200, 300 ppm), macam klon kakao (RCC 70, RCC 71, ICCRI 08H) diulang 3 kali. Data dianalisis dengan uji F jika beda nyata dilanjutkan uji BNT $5 \%$. Hasil penelitian menunjukkan konsentrasi GA3 berbeda sangat nyata terhadap semua variabel pengamatan kecuali berbeda nyata terhadap variabel diameter batang, berbeda tidak nyata pada variabel persentase berkecambah, jumlah akar primer. Konsentrasi optimum yaitu 200 ppm. Macam klon kakao berbeda sangat nyata terhadap semua variabel, kecuali berbeda tidak nyata pada persentase berkecambah. Pertumbuhan kakao terbaik pada klon ICCRI 08H. Interaksi konsentrasi GA3 dengan macam klon kakao berbeda sangat nyata pada variabel kecepatan berkecambah, tinggi tanaman, luas daun per tanaman, bobot basah tanaman, pajang akar terpanjang, volume akar, berbeda nyata pada variabel saat muncul akar, jumlah daun per tanaman, berbeda tidak nyata pada variabel persentase berkecambah, diameter batang dan jumlah akar primer. Interaksi terbaik konsentrasi GA3 200 ppm dengan klon kakao ICCRI 08H.
\end{abstract}

Kata kunci : Kakao (Theobroma cacao L.), Konsentrasi GA3, Klon kakao

\begin{abstract}
Cocoa is one of the plantation commodities that still plays an important role in increasing the foreign exchange of the country. The supply of cocoa seed is still inadequate and the quality of the resulting seed is still low. Study aimed to determine the effect of gibberellin (GA3) concentrations and types of clones on the growth of cocoa seed and the interactions. The study was conducted in the Kenconorejo Village, Tulis Sub Regency, Batang Regency. The experimental design is a complete randomized block design (CRBD) with treatments GA3 concentrations (control, 100, 200, 300), various types of cocoa clones (RCC 70, RCC 71, ICCRI 08H) and repeated 3 times. Data was analyzed using F test and continued with the Least Significant Difference (LSD) BNT if there was a significant effect on $5 \%$. The results showed that GA3 concentration was very significantly different from all variables except that it was significantly different on stem diameter, was not significantly different on the percentage of germination, the number of primary roots. The optimum concentration is $200 \mathrm{ppm}$. The types of cocoa clones was significantly different from all variables except that it was not significantly different on the percentage of germination. The best cocoa growth on ICCRI $08 \mathrm{H}$ clones. The interaction of GA3 concentration with types of cocoa clones was very significantly different in the variable speed of germination, plant height, leaf area per plant, wet weight of the plant, longest root length, root volume, significantly different in the variable when the roots appear, the number of leaves per plant, not significantly different in the variable percentage of germination, stem diameter and the number of primary roots . The best interaction of 200 ppm GA3 concentration with ICCRI 08H cocoa clones.
\end{abstract}

Keywords : Cocoa, GA3 concentration, Cocoa clones.

\section{PENDAHULUAN}

Kakao (Theobroma cacao L.) merupakan salah satu komoditas perkebunan yang masih berperan cukup penting dalam meningkatkan devisa negara (Direktorat Jenderal Perkebunan, 2012). Kakao dikenal dalam bentuk yang digunakan sebagai bahan makanan dan campuran minuman, dengan perkembangan industri yang pesat dewasa ini kakao digunakan sebagai bahan kosmetik dan obat-obatan, selain itu digunakan juga untuk pembuatan kembang gula dan manisan cokelat (Hayati 2011). Luas areal serta produktivitas total kakao pada tahun 2016 mengalami 
peningkatan dari tahun sebelumnya, luas areal kakao mencapai 1.722 .315 ha dengan produktivitas sebesar 760.429 ton (Direktorat Jenderal Perkebunan, 2016). Tahun 2017 luas lahan meningkat sebesar 1.724 .366 ha tetapi produksi mengalami penurunan yaitu menjadi sebesar 657.050 ton dan pada nilai ekspor juga mengalami penurunan yaitu sebesar 1.120.765 US\$, hal ini disebabkan penggunaan bibit tanaman yang kurang baik dan berkualitas rendah, serta teknologi budidaya yang kurang optimal (Hakiki dan Asnawi, 2019).

Kriteria bibit kakao siap tanam asal benih dapat dilihat dari tiga parameter yaitu tinggi tanaman, diameter batang, jumlah daun dan dapat digolongan menjadi 3 grade yaitu grade A (baik) dengan tinggi tanaman $>60 \mathrm{~cm}$, diameter batang $>1,0 \mathrm{~cm}$, jumlah daun $>12$ helai, grade $B$ (sedang) dengan tinggi tanaman $45-60 \mathrm{~cm}$, diameter batang 0,6-1,0 $\mathrm{cm}$, jumlah daun 10-12 helai dan grade $\mathrm{C}$ (kurang baik) dengan tinggi tanaman $<45 \mathrm{~cm}$, diameter batang $<0,6 \mathrm{~cm}$, jumlah daun $<10$ helai (Rahardjo, 2011).

Penambahan luasan lahan kebun kakao belum diimbangi dengan tersedianya bibit kakao yang mencukupi dan penyediaan bibit kakao masih rendah. Menurut Direktorat Perbenihan Perkebunan (2018) penyediaan benih kakao siap tanam Tahun 2018 mencapai 4.795 .433 batang/polybag atau $66,05 \%$ dari target 7.260 .543 batang/polybag dan masuk dalam katagori kurang berhasil, sementara masih kekurangan bibit kakao sebanyak 2.465 .110 batang/polybag.

Masalah yang sering muncul pada saat penyediaan bibit kakao adalah penyediaan bibit belum mencukupi kebutuhan dan bibit yang dihasilkan kualitasnya masih rendah yang disebabkan oleh teknik pembibitan yang dilakukan petani masih belum optimum. Menurut Riandi (2018) keberhasilan pengembangan kakao dapat ditentukan oleh tersedianya bibit dalam jumlah yang cukup dan bibit kakao berkualitas, sedangkan teknik pembibitan yang tidak optimum akan menghasilkan kualitas bibit kakao yang rendah.
Upaya untuk meningkatkan bibit kakao agar tersedia dengan cukup dan cepat adalah dengan pengaplikasian GA3, perbanyakan dengan biji atau benih pastinya terdapat proses perkecambahan biji, pada proses tersebut membutuhkan peng-aplikasian zat pengatur tumbuh agar mempercepat proses perkecambahan. Kusumo (1994) menyatakan bahwa untuk pemacuan perkecambahan biji dapat dilakukan dengan pemberian zat pengatur tumbuh (ZPT). Sedangkan ZPT yang sering digunakan untuk memacu perkecambahan biji salah satunya adalah Giberelin (GA3). Menurut Yasmin (2014) Pemberian GA3 ternyata dipengaruhi oleh konsentrasi yang diberikan, konsentrasi GA3 yang dibutuhkan oleh setiap jenis tanaman berbeda-beda. Pemberian konsentrasi GA3 yang tepat dapat mamacu pertumbuhan tanaman. Kualitas bibit dipengaruhi oleh klon bibit yang digunakan, bahan tanam yang unggul berasal dari klon yang unggul, menurut Riniarti dkk., (2013) upaya yang dapat dilakukan untuk menyediakan bibit kakao yang berkualitas adalah dengan penggunaan bahan tanam kakao dengan klon yang unggul. Menurut Danuji (2016) pemilihan bahan tanam merupakan tindakan awal yang sangat penting dalam budidaya kakao. Rahardjo (2011) klon dari benih bina kakao lindak lebih banyak digunakan dalam pembangunan perkebunan kakao rakyat, kakao jenis forestero atau kakao lindak lebih mudah dibudidayakan dan peluang pasarnya lebih besar dibandingkan kakao mulia. Penelitian ini dilakukan dengan tujuan untuk mengetahui konsentrasi GA3 yang optimum untuk memberikan hasil terbaik terhadap pertumbuhan benih dan bibit kakao, untuk mengetahui klon kakao yang mempunyai kemampuan berkecambah dan daya tumbuh paling tinggi pada pertumbuhan benih dan bibit kakao, serta untuk mengetahui interaksi antara konsentrasi GA3 dan macam klon kakao terhadap pertumbuhan bibit kakao. 


\section{METODE PENELITIAN}

Penelitian telah dilaksanakan di di Desa Kenconorejo, Kecamatan Tulis, Kabupaten Batang, Jawa Tengah, mulai bulan November 2019 sampai Maret 2020 dengan ketinggian tempat \pm 50 mdpl.

Rancangan yang digunakan dalam penelitian ini adalah Rancangan Acak Kelompok (RAK), disusun secara faktorial yang terdiri atas 2 faktor. Faktor pertama adalah konsentrasi GA3 yang terdiri atas 0 ppm (G0), 100 ppm (G1), 200 ppm (G2) dan 300 ppm (G3). Faktor kedua adalah macam klon kakao yang terdiri atas RCC 70 (K1), RCC 71 (K2) dan ICCRI 08H (K3). Masingmasing kombinasi diulang tiga kali dengan 12 kombinasi perlakuan sehingga seluruhnya ada 36 satuan percobaan. Satuan percobaan terdiri atas lima sampel tanaman sehingga seluruhnya ada $36 \times 5=180$ tanaman sampel.
Variabel yang diamati meliputi : kecepatan berkecambah, persentase berkecambah, saat muncul akar, tinggi tanaman, jumlah daun per tanaman, luas daun per tanaman, diameter batang, bobot basah tanaman, jumlah akar primer, panjang akar terpanjang dan volume akar. Data dianalisis dengan analisis sidik ragam berdasarkan uji $\mathrm{F} \quad 5 \%$ dan $1 \%$. Jika berpengaruh nyata dilanjutkan dengan uji BNT.

\section{HASIL DAN PEMBAHASAN \\ Konsentrasi $\mathrm{GA}_{3}$}

Hasil penelitian menunjukkan bahwa pengaruh konsentrasi GA3 berbeda sangat nyata terhadap variabel pengamatan kecepatan berkecambah, saat muncul akar, tinggi tanaman, jumlah daun per tanaman

Tabel 1. Angka rata-rata dan Analisis Statistik Data Penelitian Pengaruh Kosentrasi $\mathrm{GA}_{3}$ dan Macam Klon Kakao

\begin{tabular}{lccccc}
\hline \multicolumn{1}{c}{ Perlakuan } & $\begin{array}{c}\text { Kecepatan } \\
\text { berkecam } \\
\text { bah (hari) }\end{array}$ & $\begin{array}{c}\text { Saat } \\
\text { muncul } \\
\text { akar } \\
\text { (hari) }\end{array}$ & $\begin{array}{c}\text { Tinggi } \\
\text { tanama } \\
\mathrm{n}(\mathrm{cm})\end{array}$ & $\begin{array}{c}\text { Jumlah } \\
\text { daun per } \\
\text { tanaman } \\
\text { (helai) }\end{array}$ & $\begin{array}{c}\text { Luas } \\
\text { daun per } \\
\text { tanaman } \\
\text { (cm2) }\end{array}$ \\
\hline Konsentrasi GA3 & & & & & \\
G0 = ppm & $7,58 \mathrm{c}$ & $2,60 \mathrm{c}$ & $40,20 \mathrm{a}$ & $14,56 \mathrm{a}$ & $254,11 \mathrm{a}$ \\
$\mathrm{G} 1=100 \mathrm{ppm}$ & $5,00 \mathrm{~b}$ & $2,07 \mathrm{~b}$ & $41,38 \mathrm{a}$ & $15,84 \mathrm{~b}$ & $277,02 \mathrm{c}$ \\
$\mathrm{G} 2=200 \mathrm{ppm}$ & $2,16 \mathrm{a}$ & $1,49 \mathrm{a}$ & $44,51 \mathrm{~b}$ & $16,75 \mathrm{c}$ & $284,15 \mathrm{~d}$ \\
$\mathrm{G} 3=300 \mathrm{ppm}$ & $4,69 \mathrm{~b}$ & $1,98 \mathrm{~b}$ & $41,64 \mathrm{a}$ & $15,44 \mathrm{~b}$ & $264,35 \mathrm{~b}$ \\
\hline Macam Klon Kakao & & & & & \\
K1 = RCC 70 & $4,83 \mathrm{~b}$ & $2,03 \mathrm{~b}$ & $41,75 \mathrm{~b}$ & $15,69 \mathrm{~b}$ & $269,63 \mathrm{~b}$ \\
$\mathrm{~K} 2=$ RCC 71 & $6,38 \mathrm{c}$ & $2,38 \mathrm{c}$ & $38,12 \mathrm{a}$ & $13,78 \mathrm{a}$ & $241,47 \mathrm{a}$ \\
$\mathrm{K} 3=$ ICCRI 08H & $3,35 \mathrm{a}$ & $1,68 \mathrm{a}$ & $45,93 \mathrm{c}$ & $17,48 \mathrm{c}$ & $298,62 \mathrm{c}$ \\
\hline
\end{tabular}

Keterangan : Angka yang diikuti huruf yang sama pada kolom dan baris menunjukkan tidak berbeda nyata menurut uji BNT taraf $5 \%$

luas daun per tanaman, bobot basah tanaman, panjang akar terpanjang, dan volume akar, berbeda nyata pada variabel diameter batang, serta berbeda tidak nyata pada variabel persentase berkecambah dan jumlah akar primer. Konsentrasi 200 ppm merupakan konsentrasi optimum untuk pertumbuhan bibit kakao. Menurut Adnan dkk., (2017) bahwa pemberian ZPT dengan konsentrasi rendah tidak akan menunjukkan perubahan yang signifikan pada tanaman, sedangkan pemberian pada konsentrasi yang terlalu tinggi justru akan berdampak pada penurunan.

Menurut Muhtarudin (2012) Giberellin $\left(\mathrm{GA}_{3}\right)$ konsentrasi 200 ppm merupakan konsentrasi optimum yang mampu mendorong proses fisiologi tanaman meliputi perkecambahan dan pertumbuhan tanaman kakao. Benih yang berkecambah dengan cepat ditandai dengan munculnya akar yang cepat pula, hal tersebut sesuai dengan pendapat Suhendra dkk., (2016) giberelin merupakan zat pengatur tumbuh yang dapat mempercepat proses perkecambahan jika giberelin diberikan pada konsentrasi yang tepat, sehingga bermanfaat bagi tanaman. Menurut Asra (2014) tumbuhan dapat menghasilkan giberelin sendiri. Salisbury dan Ross (1995) menegaskan bahwa GA3 endogen juga dapat meningkatkan hidrolisis pati. Dengan peningkatan hidrolisis pati maka benih memiliki banyak energi untuk berkecambah, hal ini menyebabkan 
persentase pada semua perlakuan menjadi $100 \%$. Selain itu semua benih yang dikecambahkan mempunyai kemampuan berkecambah yang sama pada kondisi lingkungan dan media yang sesuai untuk perkecambahan benih kakao sehingga pemberian konsentrasi GA3 tidak berpengaruh terhadap persentase berkecambah.

Menurut penelitian Pertiwi dkk., (2014) menunjukkan peningkatan tinggi tanaman akibat penambahan konsentrasi giberelin akan menstimulasi pemanjangan sel karena adanya hidrolisis pati yang dihasilkan dari giberelin mendukung terbentuknya enzim. Semakin tinggi tanaman maka jumlah daun pada tanaman tersebut semakin bertambah, hal ini sejalan dengan pendapat Kusumawati dkk., (2009), tanaman yang ditambahkan GA3 secara eksogen akan terjadi peningkatan jumlah daun, hal ini disebabkan pemberian konsentrasi GA3 memacu pemanjangan ruasruas batang sehingga menyebabkan meningkatnya jumlah nodus (tempat tumbuh daun) pada tunas batang yang selanjutnya terjadi peningkatan jumlah daun.

Tabel 2. Angka rata-rata dan Analisis Statistik Data Penelitian Pengaruh Kosentrasi $\mathrm{GA}_{3}$ dan Macam Klon Kakao

\begin{tabular}{lccccc}
\hline \multicolumn{1}{c}{ Perlakuan } & $\begin{array}{c}\text { Diameter } \\
\text { batang } \\
(\mathrm{cm})\end{array}$ & $\begin{array}{c}\text { Bobot } \\
\text { basah } \\
\text { tanaman } \\
(\mathrm{gram})\end{array}$ & $\begin{array}{c}\text { Jumlah } \\
\text { akar primer } \\
\text { (buah) }\end{array}$ & $\begin{array}{c}\text { Panjang akar } \\
\text { terpanjang } \\
(\mathrm{cm})\end{array}$ & $\begin{array}{c}\text { Volume } \\
\text { akar } \\
(\mathrm{ml})\end{array}$ \\
\hline Konsentrasi GA3 & & & & & \\
$\mathrm{G} 0=0 \mathrm{ppm}$ & $0,50 \mathrm{a}$ & $33,52 \mathrm{a}$ & 3,02 & $32,13 \mathrm{a}$ & $18,89 \mathrm{a}$ \\
$\mathrm{G} 1=100 \mathrm{ppm}$ & $0,52 \mathrm{a}$ & $34,83 \mathrm{~b}$ & 3,04 & $35,07 \mathrm{c}$ & $22,33 \mathrm{~b}$ \\
$\mathrm{G} 2=200 \mathrm{ppm}$ & $0,53 \mathrm{ab}$ & $35,82 \mathrm{c}$ & 3,29 & $38,29 \mathrm{~d}$ & $26,89 \mathrm{~d}$ \\
$\mathrm{G} 3=300 \mathrm{ppm}$ & $0,57 \mathrm{~b}$ & $37,68 \mathrm{~d}$ & 3,18 & $33,69 \mathrm{~b}$ & $24,67 \mathrm{c}$ \\
\hline Macam klon kakao & & & & & \\
$\mathrm{K} 1=$ RCC 70 & $0,51 \mathrm{~b}$ & $35,07 \mathrm{~b}$ & $3,07 \mathrm{~b}$ & $33,98 \mathrm{~b}$ & $22,83 \mathrm{~b}$ \\
$\mathrm{~K} 2=$ RCC 71 & $0,46 \mathrm{a}$ & $32,17 \mathrm{a}$ & $2,08 \mathrm{a}$ & $30,68 \mathrm{a}$ & $16,83 \mathrm{a}$ \\
$\mathrm{K} 3=$ ICCRI 08H & $0,62 \mathrm{c}$ & $39,15 \mathrm{c}$ & $3,53 \mathrm{c}$ & $39,72 \mathrm{c}$ & $29,92 \mathrm{c}$ \\
\hline Keterangan : Angka yang dikuti huruf yang sama pada kolom dan baris menunjukkan tidak berbeda nyata menurut uji BNT \\
taraf 5\%
\end{tabular}

Bobot basah tanaman tidak terlepas dari tinggi tanaman, jumlah daun, diameter batang dan jumlah akar. Semakin besar ukuran jaringan, maka bobot basah tanaman juga akan semakin meningkat. Menurut Salisbury dan Ross (1995) bahwa pertambahan ukuran sel menghasilkan pertambahan ukuran jaringan, dan akhirnya meningkatkan ukuran tubuh tanaman secara keseluruhan maupun berat tanaman. Konsentrasi giberelin berpengaruh tidak nyata pada variabel jumlah akar primer, hal ini diduga perlakuan konsentrasi giberelin memberikan pengaruh pada pembentukan akar sekunder dan tersier yang tumbuh lebih banyak dibanding akar primer. Hidayat dkk., (2000) pada penelitian pertumbuhan akar tanaman sengon umur 6 bulan yang berasal dari biji, hasilnya menunjukkan jumlah akar sekunder $43 \%$, tersier $50 \%$ dan akar primer mencapai $7 \%$. Penambahan panjang akar dipengaruhi oleh perlakuan konsentrasi giberelin yang optimum sehingga giberelin berpengaruh pada pemanjangan sel. Menurut Mustopa (2015) pemberian konsentrasi asam giberelat dapat merangsang sintesis RNA untuk mensintesis protein, dan membentuk enzim-enzim tertentu, juga untuk mendukung perpanjangan sel. Pertumbuhan akar yang meningkat akan menghasilkan akar semakin banyak, semakin banyak akar yang tumbuh akan meningkatkan volume akar. Pada penelitian Bayu dkk., (2018) perlakuan konsentrasi giberelin berpengaruh nyata terhadap volume akar, pada tanaman yang diberi konsentrasi giberelin yang optimum volume akar akan lebih besar.

\section{Macam KIon Kakao}

Hasil penelitian menunjukkan perlakuan macam klon kakao berbeda sangat nyata terhadap semua variabel pengamatan 
kecuali berbeda tidak nyata pada variabel persentase berkecambah. Hasil penelitian menunjukkan bahwa macam klon kakao perpengaruh tidak nyata terhadap variabel persentase berkecambah, persentase pada semua klon yaitu $100 \%$, hal ini diduga lingkungan tumbuh benih kakao saat dikecambahkan telah memenuhi syarat sehingga macam klon kakao tidak berpengaruh nyata pada variabel persentase berkecambah. Perkecambahan dan pertumbuhan bibit kakao terbaik pada klon ICCRI 08H. Kecepatan berkecambah dan saat munculnya akar pada klon ICCRI $08 \mathrm{H}$ lebih cepat disebabkan oleh berat benih klon ICCRI $08 \mathrm{H}$ lebih berat yaitu 1,20 gram dari klon RCC 70 1,18 gram dan klon RCC 71 1,18 gram. Menurut Thomas (2015) bahwa kandungan endosperm akan mempengaruhi berat suatu benih, ini akan mempengaruhi kecepatan tumbuh benih, karena benih yang berat dengan kandungan endosperm yang banyak akan menghasilkan energi yang lebih besar saat mengalami proses perkecambahan. Klon ICCRI 08H merupakan klon hibrida F1 yang memiliki tingkat adaptasi terhadap lingkungan yang tinggi, sehingga laju pertumbuhan tanaman akan lebih baik dan meningkat walaupun pada lingkungan tumbuh yang baru, Hal tersebut menyebabkan hasil penelitian pada pertumbuhan tanaman klon ICCRI $08 \mathrm{H}$ lebih tinggi pada semua variabel pengamatan kecuali pada variabel persentase berkecambah. Menurut Sunanto (2006) jenis kakao hibrida yang memiliki keunggulan pertumbuhannya cepat dan mudah beradaptasi terhadap lingkungan, sehingga laju pertumbuhan tanaman menjadi lebih cepat, maka jenis kakao ini banyak diusahakan di Indonesia, karena mempunyai toleransi yang tinggi terhadap lingkungan.

Tabel 3. Angka rata-rata Interaksi Pengaruh Kosentrasi $\mathrm{GA}_{3}$ dan Macam Klon Kakao

\begin{tabular}{cllll}
\hline Perlakuan & $\begin{array}{c}\text { Kecepatan } \\
\text { berkecambah } \\
\text { (hari) }\end{array}$ & $\begin{array}{c}\text { Saat muncul } \\
\text { akar (hari) }\end{array}$ & $\begin{array}{c}\text { Tinggi } \\
\text { tanaman (cm) }\end{array}$ & $\begin{array}{c}\text { Jumlah daun } \\
\text { per tanaman } \\
\text { (helai) }\end{array}$ \\
\hline G0K1 & $7,67 \mathrm{e}$ & $2,60 \mathrm{ef}$ & $42,07 \mathrm{~cd}$ & $14,63 \mathrm{~b}$ \\
G0K2 & $8,07 \mathrm{e}$ & $2,87 \mathrm{f}$ & $35,93 \mathrm{a}$ & $13,20 \mathrm{a}$ \\
G0K3 & $7,00 \mathrm{~d}$ & $2,33 \mathrm{de}$ & $42,60 \mathrm{~cd}$ & $15,87 \mathrm{cde}$ \\
G1K1 & $4,60 \mathrm{c}$ & $1,87 \mathrm{c}$ & $43,13 \mathrm{~cd}$ & $15,80 \mathrm{~cd}$ \\
G1K2 & $7,73 \mathrm{e}$ & $2,67 \mathrm{f}$ & $36,20 \mathrm{a}$ & $13,53 \mathrm{a}$ \\
G1K3 & $2,67 \mathrm{ab}$ & $1,67 \mathrm{bc}$ & $44,80 \mathrm{de}$ & $18,20 \mathrm{f}$ \\
G2K1 & $2,13 \mathrm{ab}$ & $1,47 \mathrm{ab}$ & $43,80 \mathrm{de}$ & $16,67 \mathrm{de}$ \\
G2K2 & $2,73 \mathrm{~b}$ & $1,73 \mathrm{bc}$ & $40,27 \mathrm{bc}$ & $14,47 \mathrm{~b}$ \\
G2K3 & $1,60 \mathrm{a}$ & $1,27 \mathrm{a}$ & $49,47 \mathrm{f}$ & $19,13 \mathrm{~g}$ \\
G3K1 & $4,93 \mathrm{c}$ & $2,20 \mathrm{~d}$ & $38,00 \mathrm{ab}$ & $15,67 \mathrm{c}$ \\
G3K2 & $7,00 \mathrm{~d}$ & $2,27 \mathrm{~d}$ & $40,07 \mathrm{bc}$ & $13,93 \mathrm{ab}$ \\
G3K3 & $2,13 \mathrm{ab}$ & $1,47 \mathrm{ab}$ & $46,87 \mathrm{ef}$ & $16,73 \mathrm{e}$ \\
\hline
\end{tabular}

Keterangan : Angka yang diikuti huruf yang sama pada kolom dan baris menunjukkan tidak berbeda nyata menurut uji BNT taraf $5 \%$

\section{Interaksi antara Konsentrasi $\mathrm{GA}_{3}$ dan Macam KIon Kakao}

Hasil penelitian menunjukkan bahwa terdapat Interaksi antara konsentrasi GA3 dengan macam klon kakao berbeda sangat nyata terhadap variabel kecepatan berkecambah, tinggi tanaman, luas daun per tanaman, bobot basah tanaman, panjang akar terpanjang dan volume akar, berbeda nyata pada variabel saat muncul akar dan jumlah daun per tanaman, berbeda tidak nyata pada variabel persentase berkecam-bah, diameter batang dan jumlah akar primer. Hasil terbaik dicapai pada konsentrasi GA3 200 ppm dengan klon 
Tabel 4. Angka rata-rata Interaksi Pengaruh Kosentrasi $\mathrm{GA}_{3}$ dan Macam Klon Kakao

\begin{tabular}{ccccc}
\hline Perlakuan & $\begin{array}{c}\text { Luas daun per } \\
\text { tanaman }(\mathrm{cm} 2)\end{array}$ & $\begin{array}{c}\text { Bobot basah } \\
\text { tanaman }(\mathrm{gram})\end{array}$ & $\begin{array}{c}\text { Panjang akar } \\
\text { terpanjang } \\
(\mathrm{cm})\end{array}$ & $\begin{array}{c}\text { Volume akar } \\
(\mathrm{ml})\end{array}$ \\
\hline G0K1 & $255,79 \mathrm{c}$ & $32,91 \mathrm{bc}$ & $31,47 \mathrm{bc}$ & $18,33 \mathrm{~b}$ \\
G0K2 & $224,74 \mathrm{a}$ & $30,41 \mathrm{a}$ & $28,67 \mathrm{a}$ & $15,00 \mathrm{a}$ \\
G0K3 & $281,79 \mathrm{ef}$ & $37,25 \mathrm{gh}$ & $36,27 \mathrm{e}$ & $23,33 \mathrm{~d}$ \\
G1K1 & $276,97 \mathrm{e}$ & $35,56 \mathrm{ef}$ & $33,73 \mathrm{~d}$ & $21,00 \mathrm{c}$ \\
G1K2 & $241,77 \mathrm{~b}$ & $32,72 \mathrm{~b}$ & $30,73 \mathrm{~b}$ & $14,67 \mathrm{a}$ \\
G1K3 & $312,32 \mathrm{~g}$ & $36,20 \mathrm{fg}$ & $40,73 \mathrm{f}$ & $31,33 \mathrm{f}$ \\
G2K1 & $280,92 \mathrm{ef}$ & $34,18 \mathrm{~cd}$ & $37,73 \mathrm{e}$ & $27,67 \mathrm{e}$ \\
G2K2 & $255,87 \mathrm{c}$ & $31,05 \mathrm{a}$ & $32,27 \mathrm{bcd}$ & $20,33 \mathrm{c}$ \\
G2K3 & $315,67 \mathrm{~g}$ & $42,24 \mathrm{j}$ & $44,87 \mathrm{~g}$ & $32,67 \mathrm{f}$ \\
G3K1 & $264,86 \mathrm{~d}$ & $37,63 \mathrm{~h}$ & $33,00 \mathrm{~cd}$ & $24,33 \mathrm{~d}$ \\
G3K2 & $243,49 \mathrm{~b}$ & $34,50 \mathrm{de}$ & $31,07 \mathrm{~b}$ & $17,33 \mathrm{~b}$ \\
G3K3 & $284,70 \mathrm{f}$ & $40,90 \mathrm{i}$ & $37,00 \mathrm{e}$ & $32,33 \mathrm{f}$ \\
\hline
\end{tabular}

Keterangan : Angka yang diikuti huruf yang sama pada kolom dan baris menunjukkan tidak berbeda nyata menurut uji BNT taraf $5 \%$

ICCRI 08H (G2K3). Konsentrasi GA3 200 ppm merupakan konsentrasi yang tepat untuk pertumbuhan tanaman kakao, dan klon ICCRI $\mathrm{08H}$ memiliki kemampuan merespon pemberian konsentrasi GA3 lebih tinggi sehingga antara perlakuan konsentrasi GA3 $200 \mathrm{ppm}$ dan klon kakao ICCRI O8H memberikan hasil yang lebih tinggi. Klon ICCRI 08H merupakan klon hibrida F1 yang memiliki tingkat adaptasi yang tinggi sehingga pertumbuhan bibit klon ICCRI $08 \mathrm{H}$ lebih optimal dibanding klon lokal yaitu klon RCC 70 dan RCC 71. Menurut Lakitan (1996) pemberian konsentrasi lebih dari $200 \mathrm{ppm}$ GA3 terjadi toksik sehingga menghambat perkecambahan dan pertumbuhan tanaman. Gardner dkk., (1991) menyatakan bahwa, tanaman yang mempunyai respon dan toleransi tinggi terhadap lingkungan, maka pertumbuhan tanaman pada tahap awal akan berlangsung lebih cepat sehingga akan meningkatkan pertumbuhan vegetatif tanaman seperti akar, batang dan daun. Interaksi antara konsentrasi GA3 dan macam klon kakao dapat meningkatkan kualitas bibit kakao siap tanam sampai pada grade $B$ yaitu tinggi tanaman diperoleh hasil $49,47 \mathrm{~cm}$, diameter batang diperoleh hasil $0,62 \mathrm{~cm}$ dan jumlah daun diperoleh hasil 19,13 helai, Kualitas bibit kakao yang masih pada grade $\mathrm{B}$ masih bisa ditanam oleh petani, hal ini diperkuat oleh pendapat Direktorat Jenderal Perkebunan (2011) yang menyatakan bahwa pertumbuhan bibit kakao yang layak tanam yaitu telah mencapai tinggi minimal $20 \mathrm{~cm}$, memiliki diameter batang minimal $0,5 \mathrm{~cm}$ dan memiliki jumlah daun minimal 10 helai pada saat bibit berumur 3-6 bulan.

\section{SIMPULAN}

Berdasarkan hasil penelitian dan pembahasan dapat ditarik beberapa simpulan sebagai berikut :

1. Perlakuan Konsentrasi GA3 berpengaruh sangat nyata terhadap variabel pengamatan kecepatan berkecambah, saat muncul akar, tinggi tanaman, jumlah daun per tanaman, luas daun per tanaman, bobot basah tanaman, panjang akar terpanjang, dan volume akar, berbeda nyata pada variabel diameter batang, serta berbeda tidak nyata pada variabel persentase berkecambah dan jumlah akar primer. Konsentrasi 200 ppm merupakan konsentrasi optimum untuk partumbuhan bibit kakao.

2. Perlakuan Macam klon kakao berpengaruh sangat nyata terhadap semua variabel pengamatan kecuali berbeda tidak nyata pada variabel persentase berkecambah. Perkecambahan dan pertumbuhan bibit kakao terbaik pada klon ICCRI 08H

3. Interaksi antara konsentrasi GA3 dengan macam klon kakao berbeda sangat nyata terhadap variabel kece-patan berkecambah, tinggi tanaman, luas daun per tanaman, bobot basah tanaman, panjang akar terpanjang dan volume akar, berbeda nyata pada variabel saat muncul akar dan jumlah daun per 
tanaman, berbeda tidak nyata pada variabel persentase berkecambah, diameter batang dan jumlah akar primer. Hasil terbaik dicapai pada konsentrasi GA3 200 ppm dengan klon ICCRI 08H (G2K3).

\section{DAFTAR PUSTAKA}

Adnan, B. R. Juanda, dan M. Zaini. 2017. Pengaruh Konsentrasi dan Lama Perendaman dalam ZPT Auksin terhadap Viabilitas Benih Semangka (Citurullus lunatus) Kadaluarsa. Jurnal Agrosamudra. 4(1): 45-57

Asra. R. 2014. Pengaruh Hormon Giberelin (GA3) terhadap Daya Kecambah dan Vigoritas Calopogonium caeruleum. Jurnal Biospecies 7 (1) : 29-33.

Bayu. E.S, Atika.R, Kardhinata. E.H. 2018. Respons Pertumbuhan dan Produksi Beberapa Varietas Kacang Hijau (Vigna radiata L.) Dengan Pemberian Giberelin di Lahan salin. Jurnal Pertanian Tropik 5 (3) 384 - 390.

Danuji, S. 2016.Pertumbuhan Bibit Kakao Lindak Berasosiasi dengan Synechococcus sp. Jurnal Biologi dan Pembelajaran Biologi. Volume 1 Nomor 2 Tahun 2016.

Direktorat Jendral Perkebunan Republik Indonesia. 2016. Statistik Perkebunan Indonesia 2014-2016. Direktorat Jenderal Perkebunan, Jakarta.

2012. Luas Areal dan Produksi Perkebunan Seluruh Indonesia Menurut Pengusahaan. Direktorat Jenderal Perkebunan, Kementrian Pertanian.

, 2011. Pedoman Teknis Praktek Budidaya Kakao yang Baik. Direktorat Jenderal Perkebunan, Jakarta.

Direktorat Perbenihan Perkebunan. 2018. Laporan Kinerja Tahun 2018. Kementerian Pertanian, Direktorat Perbenihan Perkebunan, Jakarta.
Fahmi, Z. I .2013. Pengaruh Pemberian Hormon Giberelin terhadap Perkecambahan Benih Tanaman. (On line) http://ditjenbun.pertanian. go.id/bbpptpsurabaya/. Diakses Tanggal 20 April 2020.

Gardner, F.P., R.B. Pearce dan R.L. Mitchell. 1991. Fisiologi Tanaman Budidaya. UI Press. Jakarta.

Hakiki. S. I, Asnawi. 2019. Pengaruh Luas Lahan, Produksi, Harga Kakao Internasional terhadap Ekspor Kakao Indonesia. Jurnal Ekonomi Pertanian Unimal Vol.02 No.01 Mei 2019 E-ISSN: 2614-4565.

Hayati, Rita. 2011. Pengaruh Tingkat Kemasakan Buah dan Cara Penyimpanan Terhadap Viabilitas dan Vigor Benih Kakao (theobroma cacao L.). Jurnal Floratek 6: 114 123,Aceh.

Hidayat, Y., Rusdiana. O., Fakuara, Y., dan Kusmana, C. $2000 . \quad$ Respon Pertumbuhan Akar Tanaman Sengon (Paraserianthes falcataria) terhadap Kepadatan dan Kandungan Air Tanah Podsolik Merah Kuning. Jurnal Manajemen Hutan Tropika 6(2):43-53

Kusumawati, A., Endah, D.H, dan Nintya, S. 2009. Pertumbuhan dan Pembungaan Tanaman Jarak Pagar Setelah Penyemprotan GA3 dengan Konsentrasi dan Frekuensi yang Berbeda. Jurnal Penelitian Sains \& Teknologi. 10 (1):18-29.

Kusumo S. 1994. Zat pengatur tumbuh tanaman. C.V. Yasaguna. Bogor

Lakitan B. 1996. Fisiologi Pertumbuhan dan Perkembangan Tanaman. PT. Raja Grafindo Persada. Jakarta.

Mudyantini, W. 2008. Pertumbuhan, kandungan selulosa, dan lignin pada rami (Boehmeria nivea L. Gaudich) dengan pemberian asam giberelat (GA3). Jurnal Biodiversitas Vol 9, No. 4 hal 269-274. 
Muhtarudin. 2012. Respon Perkecambahan dan Pertumbuhan Bibit Beberapa Jenis Kakao (Theobroma cacao L.) Dengan Pemberian Variasi Konsentrasi Giberellin (GA3). Skripsi. Universitas Pekalongan.

Mustopa.A. S. 2015. Pengaruh Konsentrasi Asam Giberelat (GA3) dan Lama Perendaman terhadap Viabilitas, Vigor dan Pertumbuhan Benih Jarak (Jatropha curcas L.) Klon IP-1P di Pembenihan. Paspalum vol 3 no. 2.

Pertiwi, P.D., Agustiansyah, dan Y. Nurmiaty. 2014. Pengaruh Giberelin Terhadap Pertumbuhan dan Produksi Tanaman Kedelai (Glycine max L.) Merrill.). Jurnal Agrotek Tropika. 2(2):276-281.

Rahardjo, P. 2011. Menghasilkan benih \& bibit kakao unggul. Penebar Swadaya: Jakarta.

Riandi, I. 2018. Respon Pertumbuhan Bibit Tanaman Kakao (theobroma cacao L.) pada Medium Gambut dengan Pemberian Pupuk Kascing dan Dolomit. Skripsi. Fakultas Pertanian UMSU. Medan.

Riniarti, D., A. Kusumastuti., dan M. Tahir. 2013. Pengaruh Jenis Limbah Agro Industri terhadap Keragaan Bibit Sawit Main-nursery pada Ultisol. Jurnal Pertanian Terapan 13(2): 123-130.
Salisbury, F.B and C.W. Ross. 1995. Fisiologi Tumbuhan, Biokimia Tumbuhan, jilid 2. Penerjemah :Lukman, D.R. dan Sumaryono. Penerbit ITB, Bandung.

Suhendra, D., Nisa, T. C., \& Hanafiah, D. S. 2016. Efek Konsentrasi Hormon Giberelin (GA3) dan Lama Perendaman pada Berbagai Pembelahan terhadap Perkecambahan Benih Manggis (Garcinia mangostana L). Jurnal Pertanian Tropik, 3(3), 238-248.

Sunanto. 2006. Cokelat Pengolahan Hasil dan Aspek Ekonominya. Kanisius. Yogyakarta.

Thomas D. 2015. Pengaruh Berat Benih Dan Media Tanam terhadap Pertumbuhan Vegetatif Bibit Durian (Durio Zibethinus Murr), Jurnal Agrifor Volume XIV Nomor 2. ISSN : 1412 - 6885. Samarinda.

Yasmin. 2014. Pengaruh Perbedaan Waktu Aplikasi Dan Konsentrasi Giberelin (Ga3) Terhadap Pertumbuhan Dan Hasil Tanaman Cabai Besar (Capsicum annuum L.) Jurnal Produksi Tanaman. Volume 2, Nomor 5, Juli 2014, hlm. 395-403. 